\title{
AkMen \\ PENGARUH HARGA DAN NILAI TUKAR TERHADAP VOLUME EKSPOR IKAN TUNA DI PROVINSI SULAWESI SELATAN TAHUN 2003-2017
}

\author{
Fauzia F Alamri ${ }^{1}$, Fitriani Latief ${ }^{2}$, Ridwan ${ }^{3}$ \\ STIE Nobel Indonesia Makassar ${ }^{1,2,3}$ \\ Email: alamrifauzia.faa@gmail.com ${ }^{1}$, fitri@ stieobel-indonesia.ac.id ${ }^{2}$, ridwan@ $\underline{\text { stienobel- }}$ \\ indonesia.ac.id $^{3}$
}

\begin{abstract}
Abstrak
Penelitian ini bertujuan untuk: (a) mengetahui bahwa nilai tukar dan harga berpengaruh positif dan signifikan secara parsial terhadap volume ekspor ikan tuna di Sulawesi Selatan (b) mengetahui bahwa nilai tukar dan harga berpengaruh positif dan signifikan secara simultan terhadap volume ekspor ikan tuna di Sulawesi Selatan. Penelitian ini menggunakan regresi linear berganda dengan pengumpulan data sekunder. Hasil penelitian menunjukkan bahwa secara simultan variabel harga dan nilai tukar berpengaruh secara signifikan dan positif terhadap volume ekspor ikan tuna di Sulawesi Selatan. Secara parsial harga berpengaruh secara signifikan terhadap volume ekspor ikan tuna di Sulawesi Selatan dan nilai tukar berpengaruh secara signifikan terhadap volume ekpsor ikan tuna di Sulawesi Selatan.
\end{abstract}

Kata Kunci: Harga, Nilai Tukar dan Volume Ekspor

\section{Abstract}

This study aims to: (a) find out that the exchange rate and price have a partially positive and significant effect on the volume of tuna exports in South Sulawesi. (b) find out that the exchange rate and price have a simultaneous positive and significant effect on the volume of tuna exports in South Sulawesi. This study used multiple linear regression with secondary data collection. The result of this study showed that simultaneously, the price and exchange rate variables. Significantly and positively affected toward the volume of tuna exports in South Sulawesi. Partially the price had a significant effect toward the volume of tuna exports in South Sulawesi and the exchange rate also had a significant effect toward the volume of tuna exports in South Sulawesi.

Keywords: Price, Exchange Rate and Export Volume

\section{PENDAHULUAN}

Indonesia merupakan negara sangat kaya akan sumber daya alamnya, Indonesia juga di akui adalah negara surga. Kelebihan sumber daya alam ini banyak di manfaatkan oleh anak bangsa. Kekayaan alam yang berada di daerah dasar laut serta tanah dibawahnya. Kekayaan alam yang berada di daerah dasar laut dan tanah dibawahnya meliputi kekayaan hayati, yaitu: bahan tambang seperti minyak bumi, gas, dan bahan polimetalik lain. Sedangkan kekayaan alam yang berada di daerah perairan meliputi kekayaan hayati, berbagi jenis ikan, dari ukuran kecil sampai ukuran besar. Potensi dimiliki Indonesia tersebut merupakan suatu peluang dan potensi ekonomi dapat dimanfaatkan untuk kemajuan perekonomian Indonesia, serta sebagai tulang punggung pembangunan nasional. . yang di antaranya adalah kegiatan ekspor. Ekspor merupakan salah satu kegiatan utama dari perdagangan internasional, ekspor bukan hanya sebagai perluasan dari pemasaran domestik.

Target ekspor dapat di evaluasi dan sekaligus untuk merumuskan upaya-upaya antisipasi, identifikasi faktor-faktor yang mempengaruhi ekspor merupakan upaya strategis, faktor tersebut secara garis besar dapat dibagi menjadi faktor domestik antara lain mencakup kapasitas produksi, harga di pasar domestik, dan berbagi kebijakan 
domestik. Di sisi lain, faktor yang bersumber dari pasar internasional antara lain mencakup harga di pasar internasional, nilai tukar dan sisi permintaan dari negara importir produk (lubis,2013:2).

Salah satu komoditi ekspor Indonesia dihasilkan oleh sektor perikanan, sektor perikanan yang mendominasi pasar ekspor berasal dari hasil tangkapan laut. sektor perikanan yang menjadi salah satu penopang kemajuan perekenomian indonesia dari tahun 2012-2016 mengalami peningkatan naik menjadi $2.31 \%$ pertahun yang berarti produk tersebut mencapai 23.62 ribu ton Dengan nilai USD 123.85 juta. Perkembangan volume ekspor hasil laut yang demikian tinggi mencerminkan adanya peluang dan demand yang semakin besar di pasar internasional terhadap hasil laut indonesia.

Faktor yang dapat memengaruhi ekspor hasil laut Indonesia adalah nilai tukar, yang dimaksud dengan nilai tukar adalah kurs valuta asing atau kurs mata uang asing menunjukan harga atau nilai mata uang suatu negara yang dinyatakan dengan mata uang negara lain, kurs valuta asing juga dapat didefinisikan sebagai jumlah uang domestik yang dibutuhkan untuk memperoleh satu unit mata uang asing, semakin tinggi nilai mata uang asing maka akan semakin tinggi uang yang harus dibayarkan (sukirno,2010:176). Berdasarkan perkembangan sistem moneter internasional terdapat 3 sistem penetapan nilai tukar yaitu: sistem kurs tetap, sistem kurs mengambang, dan sistem kurs mengaitkan nilai mata uang suatu negara atau beberapa mata uang negara tertentu. Nilai tukar atau kurs (exchange rate) antara lain dikemukakan oleh Abimanyu adalah harga mata uang suatu Negara relative terhadap mata uang negara lain. Karena nilai tukar ini mencakup dua mata uang, maka titik keseimbanganya ditentukan oleh sisi penawaran dan permintaan dari kedua mata uang tersebut. Definisi yang lebih lengkap mengenai kurs (Exchange Rate) adalah pertukaran antara dua mata uang yang berbeda, yaitu perbandingan nilai tukar merupakan salah satu faktor penting yang mempengaruhi ekspor (dolatti,2012)

Harga internasional merupakan salah satu faktor internasional yang mempengaruhi volume ekspor sebuah komoditas. Cateora dan graham (2007:286) menjelaskan harga internasional pasar internasional. Menetapkan harga yang tepat merupakan kunci kesuksesan dan kegagalan bahkan ketika pemasar internasional memproduksi produk yang tepat, mempromosikannya dengan benar, dan ekspor pengiriman barang dan jasa yang dijual oleh penduduk negara lain untuk mendapatkan mata uang dari negara pembeli. Ketika sampai tingkat harga tertinggi, maka konsumen cenderung akan menggantikan barang tersebut dengan barang lain yang mempunyai hubungan lebih dekat dan relatif lebih murah. Sebagian besar perusahaan memulai keterlibatan mereka dalam bisnis luar negeri dengan melakukan ekspor yaitu menjual beberapa produksi reguler mereka ke luar negeri. Harga yang melekat pada setiap produk dapat mencerminkan kualitas produk itu sendiri, dimana harga untuk jenis produk-produk tertentu bukan hanya besararan uang yang dikeluarkan, tapi juga mencerminkan kualitas produk tersebut. Perdagangan akan terjadi pada suatu perbandingan harga tertentu.

Ekspor merupakan cara yang tepat untuk merasakan pengalaman bisnis internasional tanpa memerlukan sumber daya manusia dan keuangan yang terlalu besar. Ekspor langsung ataupun ekspor tidak langsung memiliki persamaan yaitu metode yang paling mudah untuk memasuki pasar intenasional. Ekspor langsung memiliki alur yang lebih kompleks karena perusahaan harus menentukan pihak yang bertanggung jawab atas bisnis ekspor perusahaan. Alur yang lebih sederhana terjadi pada ekspor tidak 
langsung karena tidak membutuhkan keahlian atau modal yang besar untuk bergabung di dalamnya.

Menurut Sadano Sukirno (2008) suatu negara mengekspor barang produksinya ke negara lain dan mereka tidak dapat memproduksi barang tersebut atau produksinya tidak dapat memenuhi keperluan dalam negeri. Faktor yang lebih penting lagi adalah kemampuan dari negara tersebut untuk mengeluarkan barang-barang yang dapat bersaing dalam pasaran luar negeri. Maksudnya, mutu dan harga barang yang di ekspor tersbut haruslah paling sedikit sama baiknya dengan yang di perjual belikan dalam pasaran luar negeri.

Melalui pertimbangan yang telah diuraikan maka kerangka kospetual penelitian ini dapat digambarkan melalui gambar kerangka konsep penelitian sebagai berikut:

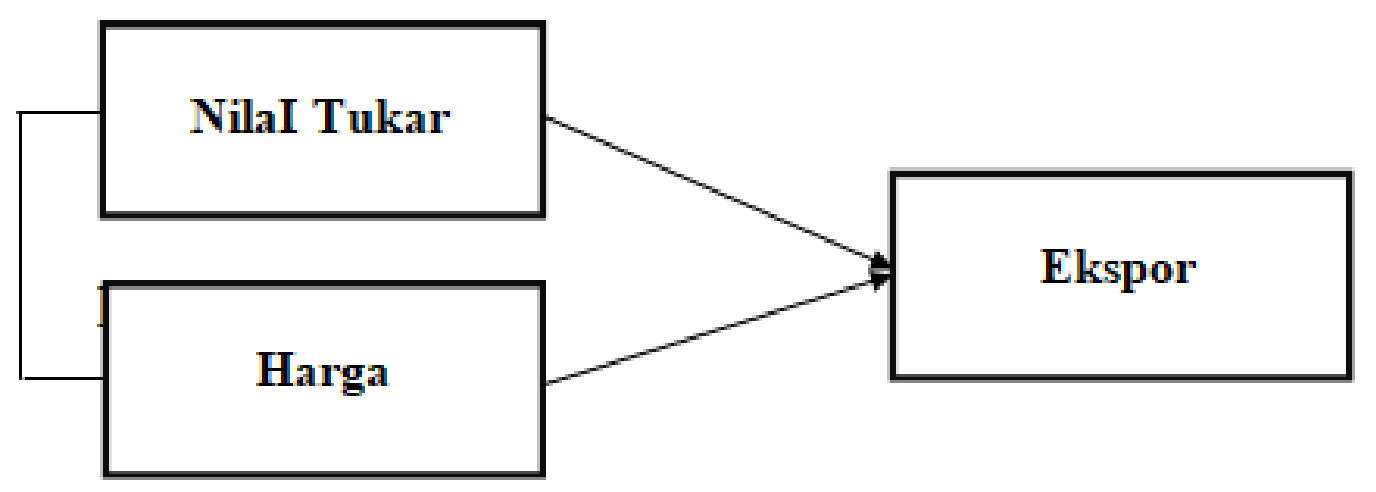

Gambar 1. Kerangka Pikir

Berdasarkan kerangka pikir, hipotesis penelitian sebagai berikut:

1. Diduga bahwa nilai tukar dan harga berpengaruh positif dan signifikan secara parsial terhadap ekspor ikan tuna di Sulawesi selatan.

2. Diduga bahwa nilai tukar dan harga berpengaruh positif dan signifikan secara simultan terhadap ekspor ikan tuna di Sulawesi selatan.

\section{METODE PENELITIAN}

Pendekatan yang digunakan dalam penelitian ini adalah pendekatan kuantitatif untuk menguji hipotesis dengan adanya hubungan antar variabel-variabel atau hubungan sebab akibat. Menurut (Sugiyono, 2017) mengemukakan bahwa Metode penelitian kuantitatif dapat diartikan sebagai metode penelitian yang berlandaskan pada filsafat positivism, digunakan untuk meneliti pada populasi atau sampel tertentu, pengumpulan data menggunakan instrument penelitian, analisis data bersifat kuantitatif/statistik, dengan tujuan untuk menguji hipotesis yang telah ditetapkan.

Penelitian kuantitatif merupakan jenis penelitian yang dapat dicapai atau diperoleh dengan menggunakan prosedur statistik atau cara lain dari kuantifikasi atau pengukuran. Penelitian ini mengkaji pengaruh nilai tukar dan harga terhadap ekspor ikan tuna di Sulawesi selatan.

\section{HASIL DAN PEMBAHASAN}

\section{Uji Asumsi Klaik}




\section{Uji Autokorelasi}

Tabel 1. Hasil Uji Autokorelasi
Model Summary
\begin{tabular}{|l|r|r|r|r|r|}
\hline Model & \multicolumn{1}{c|}{ R } & R Square & \multicolumn{1}{c|}{$\begin{array}{c}\text { Squsted R } \\
\text { Square }\end{array}$} & $\begin{array}{r}\text { Std. Error of } \\
\text { the Estimate }\end{array}$ & Durbin-Watson \\
\hline 1 &, $890^{\mathrm{a}}$ &, 791 &, 757 & $46.845,665$ & 1,876 \\
\hline
\end{tabular}

a. Predictors: (Constant), X2, X1

\section{b. Dependent Variable: $Y$}

\section{Sumber: output SPSS versi 22, data diolah}

Pada tabel 1 menunjukan bahwa nilai durbin watson sebesar 1.876 dan pada tabel durbin watson menunjukan $\mathrm{dL}=0.9455$ dan nilai $\mathrm{dU}=1.5432$ sehingga dapat disimpulkan bahwa nilai DW 1.876 lebih besar dari nilai dU=1.5432 yang artinya bahwa tidak terjadi autokorelasi.

\section{Uji Multikolinieritas}

Tabel 2. Hasil Uji Multikolinieritas Variabel bebas Coefficients $^{\mathrm{a}}$

\begin{tabular}{|c|c|c|c|c|c|c|c|c|}
\hline \multirow[b]{2}{*}{ Model } & & \multicolumn{2}{|c|}{ Unstandardized Coefficients } & \multirow{2}{*}{$\begin{array}{c}\begin{array}{c}\text { Standardized } \\
\text { Coefficients }\end{array} \\
\text { Beta }\end{array}$} & \multirow[b]{2}{*}{$t$} & \multirow[b]{2}{*}{ Sig. } & \multicolumn{2}{|c|}{ Collinearity Statistics } \\
\hline & & $B$ & Std. Error & & & & Tolerance & VIF \\
\hline \multirow[t]{3}{*}{1} & (Constant) & $-220187,893$ & 57137,656 & & $-3,854$ &, 002 & & \\
\hline & $X 1$ &, 001 &, 000 &, 570 & 4,015 &, 002 &, 863 & 1,159 \\
\hline & $\times 2$ & 21,043 & 5,928 & .504 & 3,550 &, 004 & 863 & 1,159 \\
\hline
\end{tabular}

a. Dependent Variable: Y

Sumber: output SPSS versi 22 data diolah

Berdasarkan tabel 2 diatas diketahui nilai tolerance variabel harga (X1) dan nilai tukar (X2) yakni 0,863 kedua variabel bebas memiliki nilai tolernce lebih besar dari 0,1 sementara itu VIF dari kedua variabel lebih kecil dari 10. Dimana nilai VIF harga (X1) dan nilai tukar (X2) yakni 1,159. Maka dapat disimpulkan bahwa tidak terjadi multikolonieritas.

\section{Uji Heterokedastisitas}




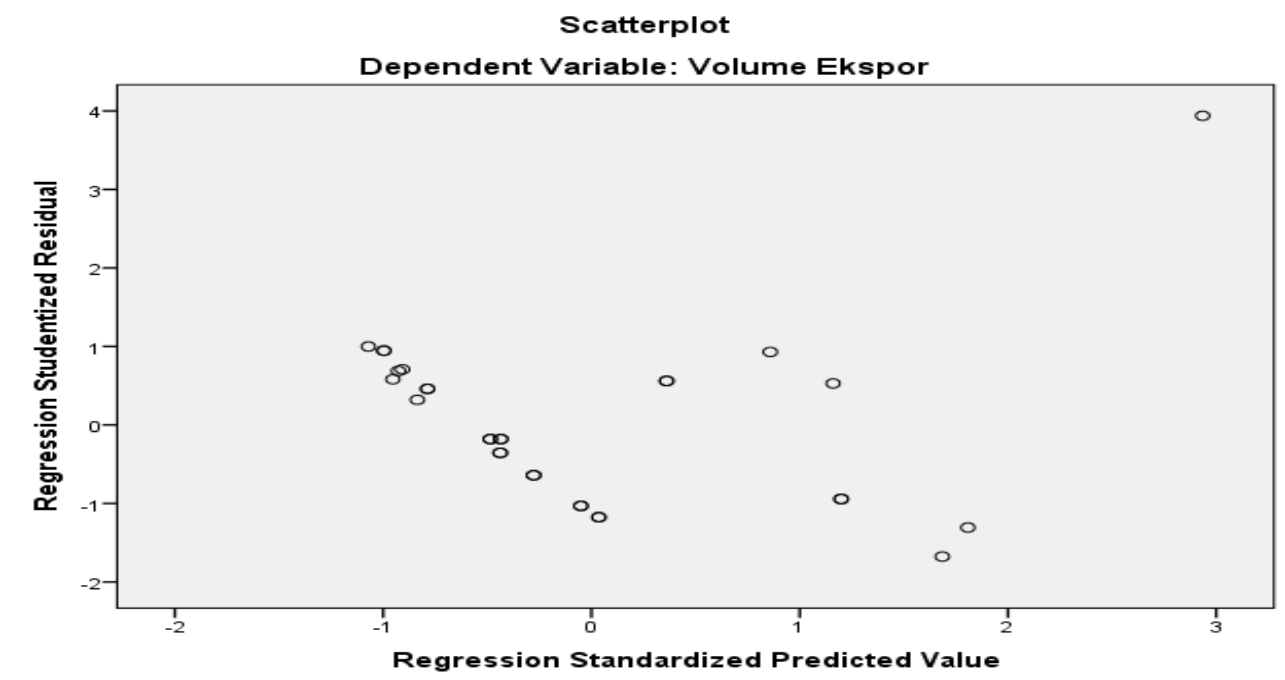

Gambar 2. Uji Heterokedastisitas

Berdasarkan output scatterpplot di atas dapat diketahui bahwa titik-titik data penyebar di atas dan di bawah atau di sekitar angka 0 dan tidak mengumpul di atas dan di bawah saja serta penyebaran titik-titik data tidak membentuk pola gelombang melebar kemudian menyempit dan melebar kembali. Dengan demikian dapat disimpulkan bahwa tidak terjadi masalah heterokedastisitas.

\section{Uji Normalitas}

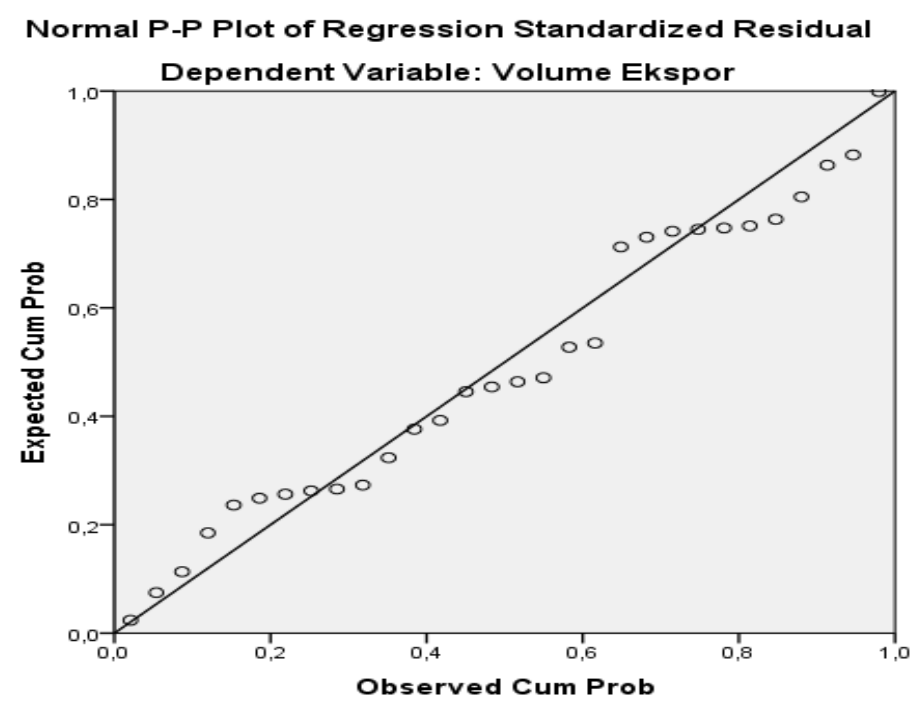

Gambar 3. Uji Normalitas

Dapat dilihat bahwa data menyebar di sekitar garis diagonal dan mengikuti arah diagonaldan di atas 0,05 , Berarti menunjukkan pola distribusi normal. Dapat disimpulkan bahwa model regresi layak dipakai karena telah memenuhi normalitas.

\section{Hasil Uji Hipotesis}

Uji Parsial (T) 
Tabel 3. Uji Parsial (T)

Coefficients $^{\mathrm{a}}$

\begin{tabular}{|c|c|c|c|c|c|c|}
\hline \multirow{2}{*}{\multicolumn{2}{|c|}{ Model }} & \multicolumn{2}{|c|}{$\begin{array}{c}\text { Unstandardized } \\
\text { Coefficients }\end{array}$} & \multirow{2}{*}{$\begin{array}{c}\begin{array}{c}\text { Standardized } \\
\text { Coefficients }\end{array} \\
\text { Beta }\end{array}$} & \multirow[b]{2}{*}{$\mathrm{T}$} & \multirow[b]{2}{*}{ Sig. } \\
\hline & & B & Std. Error & & & \\
\hline \multirow[t]{3}{*}{1} & (Constant) & $-220187,893$ & 57137,656 & & $-3,854$ &, 002 \\
\hline & $\mathrm{X} 1$ & ,001 & ,000 &, 570 & 4,015 & ,002 \\
\hline & $\mathrm{X} 2$ & 21,043 & 5,928 &, 504 & 3,550 & ,004 \\
\hline
\end{tabular}

a. Dependent Variable: Y

Sumber: output SPSS 22, data diolah

Berdasarkan hasil pengelolahan data di atas terdapat diperoleh thitung untuk masing-masing variabel yaitu dengan demikian harga (X1) sebesar 4.015<ttabel3,054 dan terlihat pada kolom signifikan bahwa nilai $\alpha$ dari harga (X1) adalah sebesar 0,002 $<$ dari 0,005, maka Ho ditolak dan Ha diterima. Artinya bahwa harga (X1) berpengaruh signifikan terhadap volume ekspor ikan tuna.

Berdasarkan hasil perhitungan kooefisien regresi secara parsial pada tabel 4 di peroleh nilai $\mathrm{t}$ hitunguntuk variabel bebas nilai tukar (X2) sebesar 3,550 dan nilai $\mathrm{t}$ tabel $>3,054$, terlihat pada kolom signifikan bahwa nilai $\alpha$ dari nilai tukar (X2) sebesar 0,04 lebih kecil dari 0,05. Maka pada tingkat kekeliuran 5\% Ho di tolak dan Ha diterima. Dapat dikatakan bahwa nilai tukar berpengaruh signifikan terhadap volume ekspor (Y).

\section{Uji Simultan (Uji F)}

Tabel 4. Uji Simultan (F)

\begin{tabular}{|c|c|c|c|c|c|c|}
\hline \multicolumn{7}{|c|}{ ANOVA $^{a}$} \\
\hline \multicolumn{2}{|c|}{ Model } & $\begin{array}{l}\text { Sum of } \\
\text { Squares }\end{array}$ & Df & Mean Square & $\mathrm{F}$ & Sig. \\
\hline 1 & Regression & $\begin{array}{r}9987542397 \\
6,761\end{array}$ & 2 & $\begin{array}{r}4993771198 \\
8,381\end{array}$ & 22,756 &, $000^{b}$ \\
\hline & Residual & $\begin{array}{r}2633419549 \\
4,972\end{array}$ & 12 & $\begin{array}{r}2194516291 \\
248\end{array}$ & & \\
\hline & Total & $\begin{array}{r}1262096194 \\
71,733\end{array}$ & 14 & & & \\
\hline
\end{tabular}

a. Dependent Variable: Y

b. Predictors: (Constant), X2, X1

sumber: output SPSS versi 22, data diolah

Berdasarkan output di atas diketahui nilai signifikan untuk pengaruh $\mathrm{X} 1$ dan X2 secara simultan terhadap $Y$ adalah sebesar $0,000<0,05$ dan nilai $F$ hitung $22,756<3,89 \mathrm{~F}$ tabel, sehingga dapat disimpulkan bahwa berpengaruh secara simultan bepengaruh 
signifikan terhadap variabel terikat volume ekspor ikan tuna.

\section{Koefisien Determinasi}

\section{Tabel 5. Hasil Koefisien Determinasi Model Summary}

\begin{tabular}{|l|r|r|r|r|r|}
\hline Model & \multicolumn{1}{|c|}{$\mathrm{R}$} & R Square & \multicolumn{1}{c|}{$\begin{array}{c}\text { Adjusted R } \\
\text { Square }\end{array}$} & $\begin{array}{c}\text { Std. Error of } \\
\text { the Estimate }\end{array}$ & Durbin-Watson \\
\hline 1 &, $890^{2}$ &, 791 &, 757 & $46.845,665$ & 1,876 \\
\hline
\end{tabular}

a. Predictors: (Constant), X2, X1

\section{b. Dependent Variable: Y}

Sumber: output SPSS 22, data diolah

Jika dilihat dari nilai $\mathrm{R}$ square yang besarnya 0,791 menunjukan bahwa proporsi pengaruh variabel harga dan nilai tukar terhadap volume ekspor sebesar 79,1\%. Yang artinya tingkat harga dan nilai tukar rupiah memiliki proporsi pengaruh terhadap terhadap ekspor ikan tuna sebesar 79,1\% sedangkan sisanya 20,3\% (100\% - 79,1\%) di pengaruhi oleh variabel lain atau fakta-fakta lain yang tidak ada dalam penelitian ini.

\section{Pembahasan \\ Harga (X1)}

Hasil pengujian statistik dengan parsial (uji t) menunjukkan bahwa variabel harga berpengaruh positif dan signifikan terhadap volume ekspor ikan tuna. Hal ini di buktikan terdapat diperoleh $\mathrm{t}$ hitung untuk masing-masing variabel yaitu dengan demikian harga (X1) sebesar $4.015<\mathrm{t}$ tabel 3,054 dan terlihat pada kolom signifikan bahwa nilai $\alpha$ dari harga (X1) adalah sebesar $0,002<$ dari 0,005, maka Ho ditolak dan Ha diterima. Artinya bahwa harga (X1) berpengaruh signifikan terhadap volume ekspor ikan tuna. Maka volume ekspor ikan tuna mengalami penurunan secara nyata.

Oleh karena itu harga merupakan salah satu variabel yang memiliki pengaruh nilai ekspor hasil perikanan dan kelautan di sulawesi selatan.

Hal ini semakin di perkuat oleh penelitian terdahulu agus setiawan (2014), corina rustan (2017), fitri andani bafadal (2016) mengemukakan bahwa nilai tukar berpengaruh signifikan terhadap volume ekspor.

\section{Nilai Tukar (X2)}

Hasil pengujian statistik dengan parsial (uji t) menunjukkan bahwa variabel nilai tukar (X2) berpengaruh positif dan signifkan terhadap volume ikan tuna.

Berdasarkan hasil perhitungan kooefisien regresi secara parsial pada tabel 4.9 di peroleh nilai t hitunguntuk variabel bebas nilai tukar (X2) sebesar 3,550 dan nilai t tabel> 3,054, terlihat pada kolom signifikan bahwa nilai $\alpha$ dari nilai tukar (X2) sebesar 0,04 lebih kecil dari 0,05. Maka pada tingkat kekeliuran 5\% Ho di tolak dan Ha diterima. Hal ini berarti peningkatan nilai tukar berbanding lurus dengan peningkatan jumlah ekspor ikan tuna. Dapat dikatakan bahwa nilai tukar berpengaruh signifikan terhadap volume ekspor (Y). 
Hal tersebut mendukung konsep teori penawaran seperti yang dijabarkan rahdja dan manurung (2006:28) dimana nilai tukar berpengaruh terhadap barang ekspor sebab nilai tukar sangat ditentukan oleh perubahan nilai mata uang antar dua negara. Menjual barang pada pasar internasional akan lebih menguntungkan dalam hal mata uang lokal karena fakta bahwa mata uang lokal lemah terhadap mata uang asing. Hal ini juga bekerja individu. Misalnya jika seorang pengusaha menjual mata uang sebesar 100 dollar yang sebelumnya 50 untuk satu dollar, ini berarti bahwa ia dapat menjual barang untuk dollar yang biasa dan menghasilkan uang dua kali lebih banyak dalam hal mata uang lokal berdasarkan perbuahan nilai tukar.

Hal ini semakin diperkuat oleh hasil penelitian terdahulu yang dilakukan devira sagita putri, mochmamad al mussadieq, supriono (2016), junaedy angkow, kiki ardi rhesayawan (2013), bahwa nilai tukar berpengaruh secara signifikan terhadap volume ekspor ikan tuna.

\section{Pengaruh Dominan}

Dari pembahasan kedua variabel bebas yang di analisis dapat dilihat bahwa tingkat dominan masing-masing variabel bebas tersebut menjadi pertimbangan volume ekspor. Dapat dikemukakan bahwa variabel bebas yang paling berkontribusi dominan dalam meningkatkan volume ekspor adalah variabel harga (X1) hal ini dapat di buktikan dengan besarnya t hitungvariabel harga (X1) sebesar 4,015 serta nilai B 0,01 lebih besar dari t hitungnilai tukar (X2) sebesar 3,550 serta nilai B sebesar 21,043.

Hal ini dengan diperkuat oleh hasil penelitian terdahulu yang dilakukan oleh agus setiawan (2014), fitri andani bafadal (2016) siti aisyah (2016) bahwa harga merupakan faktor dominan terhadap harga ekspor ikan tuna di sulawesi selatan.

\section{KESIMPULAN}

1. Hasil penelitian menunjukkan nilai tukar dan harga berpengaruh positif dan signifikan secara parsial terhadap ekspor ikan tuna di sulawesi selatan.

2. Hasil penelitian menunjukkan nilai tukar dan harga berpengaruh positif dan signifikan secara simultan terhadap ekspor ikan tuna di sulawesi selatan.

\section{DAFTAR PUSTAKA}

Agus Setiawan(2016) pengaruh nilai tukar, pertumbuhan ekonomi, harga ekspor terhadap ikan tuna indonesia tahun 2002-2014. Fakultas ekonomi dan bisnis universitas islam negeri syarif hidayatullah jakarta. Skripsi.

Arif, M. NurRianto Al dan Euis Amalia. (2010), Teori Mikroekonomi, Jakarta: Kencana

Amir MS. (2004). Strategi Memasuki Pasar Ekspor. Jakarta: PPM.

Aisyah Sitti, (2013) Pengaruh inflasi dan kurs terhadap ekspor ikan laut. Stie Nobel Indonesia, Makassar.Skripsi.

Boediono.(2013).Ekonomi Micro, cet 18, Yogyakarta: BPEE Yogyakarta. Dinas Perindustrian Dan Perdagangan Kota Makassar 2017.

Fitri Andani Bafadal (2015) pengaruh kurs,harga, dan inflasi terhadap volume ekspor rumput laut di provinsi sulawesi selatan. Stie nobel Indonesia makassar. 
Proposal.

Ghozali imam (2011) aplikasi analisis multivariate dengan program SPSS.semarang: Bp universitas diponegoro.

Nur Annisa Harbi (2018)Pengaruh inflasi, nilai tukar terhadap volume rumput laut di provinsi sulawesi selatan. stienobel Indonesia. Makassar. Skripsi.

Parrel tua halomoan simanjuntak, mukhamad kholid mawardi, zainul arifin (2017) Pengaruh produksi,harga internasional dan nilai tukar terhadap volume ekspor rumput laut indonesia. Universitas brawijaya malang. Journal.

Sugiyono.(2009). metode penelitian kuantitatif, kualitatif, dan R\&D. Bandung: alfabeta.

Sugiyono.(2015). Metode penelitian kombinasi (mix methods). Bandung. Alfabeta.

Sukirno, Sadono. (2009), Mikro Ekonomi, Jakarta: Raja Grafindo Persada.

Supriono, musadieq, devira. (2016) pengaruh harga ekspor dan nilai tukar terhadap ekspor (studi pada volume ekspor ikan tuna indonesia ke jepang).

Yusuf, dr. a muri. (2017), Metode penelitian kuantitatif, kualitatif \& penelitian gabungan, Jakarta: kencana.

Waluyo, Indarto dan Subroto J. (2007). Ekonomi Kontekstual:

Wilopo, edy yulianto, lalan gugus aditama (2015) pengaruh produksi dan nilai tukar terhadap volume ekspor. Universitas brawijaya malang. Journal. 